3 Soniachna str., e-mail: olena_polova@i.ua).

BONDARENKO-BEREGOVYCH Valeriia - postgraduate student of the fourth year of study of the Department of Audit and State Control, Vinnytsia National Agrarian University (21008, Vinnytsia, 3 Soniachna str., e-mail: ndekc2019@ukr.net).

ПОЛЕВАЯ Елена Леонидовна - доктор экономических наук, доцент заведующая кафедры аудита та государственного контроля, Винницкий национальный аграрный университет $(21008$, г. Винница, ул. Солнечная, 3, e-mail: olena_polova@i.ua).

БОНДАРЕНКО-БЕРЕГОВИЧ Валерия Валентиновна - аспирантка четвертого года обучения кафедры аудита и государственного контроля, Винницкий национальный аграрный университет (21008, г. Винница, ул. Солнечная, 3, e-mail: ndekc2019@ukr.net).

ПОРІВНЯЛЬНИЙ

АНАЛІЗ

ОПТИМАЛЬНОГО

ПЛАНУ УПРАВЛІННЯ

РЕСУРСНИМ

ПОТЕНЦІАЛОМ
КОЧЕТКОВ О.В., кандидат економічних наук, завідувач кафедри менеджменту, права, статистики та економічного аналізу

АФАНАСОВА Ю.О.,
аспірантка четвертого року навчання,
кафедри менеджменту, права,
статистики та економічного аналізу Луганський національний аграрний університет

(м. Старобільськ)

У статті проаналізовано передумови формуванні оптимального плану управління ресурсним потенціалу сільськогосподарського підприємства, щзо дозволяє отримати максимальний прибуток із забезпеченням прийнятної динаміки змін ресурсного потенціалу.

Встановлено, шо максимальний рівень економічної віддачі можливий за умови відповідного чергування ресурсовідновлюючого та інтенсивного режиму ресурсокористування. Причому, використання ресурсовиснажного режиму є неефективним навіть в особливих економічних умовах через те, щя післядія виснажливого господарювання критично знижує ресурсний потенціал аграрного підприємства.

Обтрунтовано, щуо оптимальний план, за пропонованим механізмом управління ресурсним потенціалом, має більще спільних рис із інтенсивним режимом ніж із ресурсовідновлюючим, щяо свідчить про пріоритетну господарську спрямованість оптимального управління виробничими ресурсами, а ресурсовідновлювальна практика $\epsilon$ необхідним інструментом забезпечення сталого рівня ресурсного потенціалу.

За результатами порівняльного аналізу з альтернативними сценаріями розвитку практики управління ресурсним потенщіалом доведено ефективність оптимального плану. За допомогою ефективного управління виробничими умовами, щзо формують ресурсний потенціал аграрних підприємств, формуються конкурентні переваги у вигляді додаткових 
економічних переваг, які формують додаткові умови відтворення виробничих ресурсів аграрного підприємства, щчо є основою для його сталого розвитку.

Запропоновано використання принципів динамічного програмування в системі управління ресурсним потенціалом аграрних підприсмств. Динамічне програмування визначено ефективною альтернативою адаптачійним механізмам вдосконалення управління ресурсним потенціалом аграрних підприємств. Головною перевагою вважається реалізація функиії иілепокладання системи менеджменту в систему стратегічного планування розвитку підприємства.

Ключові слова: управління, ресурсний потенціал, режим ресурсокористування, оптимальний план, ефективність, прибутковість.

Табл.: 5. Рис.: 4. Літ.: 10.

\title{
COMPARATIVE ANALYSIS OF THE OPTIMAL PLAN OF RESOURCE MANAGEMENT
}

\author{
KOCHETKOV Oleksii, \\ PhD in Economics, \\ Head of the Department of Management, \\ Law, Statistics and Economic Analysis, \\ AFANASOVA Julia,
graduate student of the fourth year of study,
Lugansk National Agrarian University \\ (Starobilsk)
}

The prerequisites of optimal plan for resource management of an agricultural enterprise to get the maximum profit with ensuring acceptable dynamics of resource potential are analyzed in the article.

It is established that the maximum level of economic return is possible in special condition with corresponding alternation of resource-restoring and intensive mode. Moreover, the intensive mode is inefficient in special economic conditions due the aftereffect of this mode critically reduces the resource potential of an agricultural enterprise.

It is proved that the optimal plan of the proposed mechanism resource management has common features with an intensive resource using mode than with a resource-restoring one. It indicates about the economic orientation of optimal resource management. The resource-restoring practice is a necessary tool for ensuring a sustainable level of resource potential.

Based on the results of a comparative analysis with alternative scenarios for the development of resource management practices, the effectiveness of the optimal plan is proved. Effective management of production conditions that form the resource potential of agricultural enterprises creates competitive advantages in the form of additional economic benefits. This is a necessary prerequisite for the reproduction of resources of an agricultural enterprise as the basis of sustainable development of agricultural enterprises.

It is proposed to use the principles of dynamic programming in the resource management of agricultural enterprises. Dynamic programming is defined as an effective alternative to adaptive mechanisms for improving the management of the resource potential of agricultural enterprises. The main advantage is the implementation of the goal-setting function of the management system in the system of strategic planning of enterprise development.

Keyword: management, resource potential, resource management mode, optimal plan, efficiency, profitability.

Tabl.: 5. Fig.: 4. Lit.: 10. 


\title{
СРАВНИТЕЛЬНЫЙ АНАЛИЗ ОПТИМАЛЬНОГО ПЛАНА УПРАВЛЕНИЯ РЕСУРСНЫМ ПОТЕНЦИАЛОМ
}

\author{
КОЧЕТКОВ А.В., \\ кандидат экономических наук, \\ заведующий кафедрой менеджмента, права, \\ статистики и экономического анализа \\ АФАНАСОВА Ю.А., \\ аспирантка четвертогогода обучения, \\ кафедры менеджмента, права, \\ статистики и экономического анализа \\ Луганский национальный аграрный университет \\ (2. Старобельск)
}

В статье проанализированы предпосылки формировании оптимального плана управления ресурсным потенциалом сельскохозяйственного предприятия, которые позволяют получить максимальную прибыль с обеспечением приемлемой динамики изменений ресурсного потенциала.

Установлено, что максимальный уровень экономической отдачи возможен при условии соответствующего чередования ресурс восстанавливающего и интенсивного режима ресурсопользования. Причем, использование ресурсоемкого режима является неэффективным даже в особых экономических условиях из-за того, что последействие истощительного хозяйствования критически снижает ресурсный потенщиал аграрного предприятия.

Обосновано, что оптимальныци план по предлагаемому механизму управления ресурсным потенциалом имеет больше общих черт с интенсивным режимом, чем с ресурс восстанавливающим, что свидетельствует о приоритетном хозяйственном направлении оптимального управления производственными ресурсами, а ресурс восстанавливающая практика является необходимым инструментом обеспечения устойчивого уровня ресурсного потенциала.

По результатам сравнительного анализа с альтернативными сиенариями развития практики управления ресурсным потенциалом доказана эффективность оптимального плана. С помощью эффективного управления производственными условиями, формируют ресурсный потенщиал аграрных предприятий, формируются конкурентные преимущества в виде дополнительных экономических преимуществ, которые формируют дополнительные условия воспроизводства производственных ресурсов аграрного предприятия, является основой для устойчивого развития.

Предложено использование принщипов динамического программирования в системе управления ресурсным потенциалом аграрных предприятий. Динамическое программирование определено эффективной альтернативой адаптационным механизмам совершенствования управления ресурсным потенциалом аграрных предприятий. Главным преимуществом считается реализация функиии целеполагания системы менеджмента $в$ систему стратегического планирования развития предприятия.

Ключевые слова: управление, ресурсный потенциал, режим ресурсопользования, оптимальный план, эффективность, доходность, альтернативы.

Табл.: 5. Рис.: 4. Лит.: 10. 
Постановка проблеми. Головною проблемою використання економікоматематичних моделей для визначення оптимального плану ресурсокористування $є$ переважно локальний часовий параметр у постановці завдання. Але найкращий план використання при визначеній структурі виробництва та поточного ресурсного потенціалу може бути неефективним при зміні обставин. Більш того, введення обмежень на балансове ресурсокористування обмежує динаміку вірогідних змін стану ресурсного потенціалу.

В реальних обставинах сталість ресурсного потенціалу $є$ важливим завданням менеджменту аграрного підприємства, проте в умовах мінливого ринкового середовища це завдання стає занадто дорогим інвестиційним проектом. Тому перспективним $\epsilon$ динамічне моделювання ефективного ресурсокористування. Таке моделювання, крім наочності, дозволяє порівнювати звичайний метод оптимізації виробництва, який орієнтований на поточну вигоду, тобто максимізації прибутку в даному річному циклі, 3 ефектом планування на довгострокову перспективу при оптимізації тільки на один крок вперед. Таким чином можна надати економічну оцінку управлінській практиці ефективного ресурсокористування.

Аналіз останніх досліджень і публікацій. Для вирішення проблеми протирічь ресурсних та підприємницьких інтересів розроблені відповідні економічні моделі та рекомендації.

Проблема формування способів ефективного управління ресурсами підприємства в процесі організації господарської діяльності досліджувалась такими відомими економістами, як Андрійчук В.Г., Гайдуцький П.I., Крисальний О.В., Месель-Веселяк В.Я., Пасхавер Б.Й., Саблук П.Т., Стельмащук А.М., Трегобчук В.М. та іншими.

Рішення з економічної оцінки ефективності управління ресурсами, які можуть представляти основу вдосконалення механізму управління ресурсним потенціалом, пропонують: Білоусенко М.В. [1], Вініченко I.I. [2], Сидорук Б.О. [3], Міценко Н.Г. [4], Піняга Н.О. [5], Росcoха В.В. [6], Сердак С.Е. [7], Трегобчук В.М. [8], Туровець О.О. [9], Федонін О.С. [10]. В той же час особливі умови реалізації планових завдань щодо вдосконалення практики землеробства потребують детального осмислення та інтеграції в систему управління ресурсним потенціалом аграрних підприємств.

Формулювання цілей статті. Метою дослідження $\epsilon$ отримання оптимального плану ресурсокористування за динамічною моделлю та здійснення порівняльного аналізу цього плану управління ресурсним потенціалом із основними альтернативами.

Виклад основного матеріалу дослідження. При побудові економікоматематичної моделі визначення оптимальної стратегії управління ресурсним потенціалом аграрного підприємства прийнято наступне допущення щодо використання виробничої функції в розрахунках.

Загальноприйнятим фактом розробки виробничих функцій для планування виробничих ресурсів $є$ визначення функціональної залежності між факторами виробництва (ресурсами) і формуванням результатів господарської 
діяльності. Визначення показників еластичності виробничої функції дозволяє проектувати можливості рівноцінної заміни ресурсів.

У пропонованій моделі розробки плану оптимального режиму ресурсокористування, виробничі функції використовуються для відображення факту ресурсної «перебудови» 3 метою зміни результативності. Тобто, виробнича функція $\epsilon$ узагальненим показником зміни стану ресурсного потенціалу при незмінному рівні продуктивної віддачі. У звичайних умовах зміна результативності виробничої системи $є$ наслідком зміни продуктивності (продуктивного виходу) при новому рівні та/або структурі ресурсного забезпечення. Тобто, процес протікає за такою схемою: зміни в ресурсному забезпеченні тягнуть зміни в продуктивності системи і утворюють новий результат. Відстежувати весь ланцюжок досить складно при плануванні, тому в якості умовності вводимо поняття нормативності в даний процес. Приймаємо, що заданому мінімальному рівню ресурсного забезпечення виробничого процесу (в технології землеробства) відповідає мінімальний рівень продуктивності (наприклад, врожайність культур). Зміни в обсязі і структурі ресурсного забезпечення, що визначають ресурсний потенціал, провокують зміни реакції виробничої системи у формуванні результату. Очевидно, що даний процес безперервний, але для зручності планування приймаємо, що існують порогові значення цих змін, що переводять виробничу систему на новий рівень. Це можна відобразити наступною формулою:

Y - економічний результат;

$$
\mathrm{Y}=\operatorname{Prod}_{\min } * \mathrm{f}(\mathrm{x})_{\text {step }}
$$

$\operatorname{Prod}_{\min }$ - мінімальна продуктивність (врожайність) при прийнятому одиничному кроці ресурсного забезпечення;

$\mathrm{f}(\mathrm{x})_{\text {step }}$ - ступінчастий показник виробничої функції, що відображає стан ресурсного забезпечення.

Використання представленої умовності полегшує процес планування змін ресурсного потенціалу в довгостроковій перспективі на основі врахування фактору впливу технологічних рішень на економічний результат у спрощеній формі.

3 іншого боку, поряд із можливістю зміни результативності за допомогою технологічних рішень, існує загальний запас (ресурсного потенціалу) виробничих ресурсів сільськогосподарського підприємства. Для забезпечення економічного результату (виробництва продукції) за допомогою технологічної системи проводиться мобілізація ресурсного потенціалу, тобто наявних корисних якостей, у процес створення продукту.

Очевидно, що використання ресурсного потенціалу має бути пов'язане 3 його відновленням. Наприклад, споживання (мінералізація) органічної речовини при вирощуванні сільськогосподарських культур вимагає операцій із заповнення дефіциту. Для цього проектуються технологічні операції внесення органічних добрив. Тому в пропонованій моделі необхідно ввести поняття стану ресурсного потенціалу і негативного (при споживанні) / позитивного (при відновленні) впливу на нього прийнятих режимів ресурсокористування. 
Відповідно, стан ресурсного потенціалу також краще відображати у вигляді ступінчастої системи.

Таким чином, задача планування оптимального стратегічного управління ресурсним потенціалом сільськогосподарського підприємства полягає у тому, щоб визначити склад технологічних режимів на кожному етапі в довгостроковій перспективі, при якому оптимальним чином забезпечується реалізація завдань ресурсокористування, тобто забезпечується максимально можливий прибуток у заданих умовах, при дотриманні практики сталого ресурсокористування, та стан ресурсного потенціалу підтримується на прийнятному рівні.

Вихідним етапом побудови моделі динамічного програмування $\epsilon$ визначення економічних показників, що відображають ефективність рішень i динаміку іiі формування на кожному етапі.

Кількість етапів визначається виходячи 3 прийнятої сівозміни, а конкретніше кількості етапів сівозміни, на яких створюється продукт. У даному випадку прийнято шестипільну сівозміну, в якій присутній чистий пар. Отже, для динамічної моделі визначено 5 етапів. Вартість обробки чистого пара враховується в загальному проекті сівозміни і бере участь в будь-якому плані, знижуючи його результативність на постійну величину. Через те, що витрати на обробку чистого пару прямим чином не беруть участь у формуванні ефективності використання ресурсного потенціалу, етап чистого пара в розрахунок не включається.

Кількість станів, що визначають показники формування та використання ресурсного потенціалу приймається суб'єктивно. В даному випадку кількість станів визначено у вигляді чотирьохрівневої шкали: 1 - незадовільний стан ресурсного потенціалу; 2 - задовільний (або достатній) стан ресурсного потенціалу; 3 - добрий (або прийнятний) стан ресурсного потенціалу; 4 відмінний, найкращий стан ресурсного потенціалу. Очевидно, що нижче незадовільного i вище відмінного стану ознака розвиватися не може. Наприклад, стосовно земельних ресурсів, як природної частини ресурсної бази аграрних підприємств стан 1 відповідає рівню природного самовідновлення 3 низьким темпом накопичення і віддачі поживних речовин. Відмінний рівень відповідає за реалізацію потенціалу продуктивності сільськогосподарських культур у заданих природних умовах.

На наступному етапі визначається набір технологічних режимів для кожної культури на заданих етапах рішення. Враховуючи попередні дослідження технологічних рішень сільськогосподарських підприємств, відзначимо, що конкретна їх ідентифікація за походженням $\epsilon$ складним процесом через те, що в рамках конкретних підприємств вони страждають значним суб'єктивізмом у реалізації.

Отже, раціонально буде ввести відповідну класифікацію за характером впливу на ресурсний потенціал. Тому прийнято наступні режими ресурсокористування, які визначають рівень технологічного навантаження на процес реалізації ресурсного потенціалу (табл. 1). 
Таблиия 1

Прийняті режими ресурсокористування

\begin{tabular}{|c|c|}
\hline Типи планів & Абревіатура \\
\hline Ресурсовідновлюючий & РсВдн \\
\hline Ресурсоощадний & РсОщд \\
\hline Інтенсивний & Інтенс \\
\hline Ресурсовиснажний & РсВсн \\
\hline
\end{tabular}

Джерело: розроблено авторами

Щодо представлених типів дій менеджменту аграрних підприємств, то відзначимо суттєвий принцип, який характеризує особливості діяльності. Головною особливістю дії за ресурсовідновлюючим планом $є$ пріоритетне використання наявних можливостей забезпечення прогресу якісного стану ресурсного потенціалу.

В системі пріоритетів прогрес ресурсів має вищий ранг від забезпечення максимальної прибутковості. Такий режим дії актуальний для підприємств із початковим низьким рівнем якості ресурсного потенціалу і грунтується на формуванні умов розширеного відтворення виробничих ресурсів.

Ресурсоощадний план дій характеризується переважно збалансованим режимом ресурсокористування, тобто забезпечення умов кругообігу корисних властивостей ресурсів впродовж виробничого періоду. Для даного режиму ресурсокористування типовою тактикою $\epsilon$ формування умов простого відтворення виробничих ресурсів.

План дій за інтенсивним режимом ресурсокористування відрізняється вищою пріоритетністю завдань забезпечення прибутковості виробничої моделі аграрного підприємства перед розвитком ресурсного потенціалу. Але передумовою розвитку прибутковості сільськогосподарської діяльності $\epsilon$ первинне формування якісного ресурсного потенціалу, тобто розвиток обставин природного простого відтворення ресурсів.

План дій за ресурсовиснажним режимом ресурсокористування не $\epsilon$ пріоритетним для сталого розвитку аграрних підприємств, але, тим не менше, $\epsilon$ типовим для поточного господарювання.

Це пов'язано, передусім, із недосконалістю економічних умов функціонування аграрних підприємств. Наявність даного виду ресурсокористування (плану), як альтернативи реалізації господарської активності в моделі планування, дозволяє визначити передумови зниження інтересу до якісного стану ресурсного потенціалу.

У таблиці 2 представлені техніко-економічні параметри вирощування озимої пшениці, а також вплив на стан ресурсного потенціалу з використанням чьотирьох технологічних режимів.

За даними таблиці 2 відзначимо, що використання ресурсовідновлювального режиму при вирощуванні озимої пшениці (Пш_РсВдн) на площі 1 га вимагає витрачання 10679 грн. При цьому стан ресурсного потенціалу поліпшується на 1 одиницю. 
Таблиия 2

Основні параметри проектних режимів ресурсокористування для вирощування озимої пшениці (Пш) на 100 га посівної площі, тис. грн.

\begin{tabular}{|l|c|c|c|c|}
\hline \multicolumn{1}{|c|}{ Параметри } & Пш_РсВсн & Пш_РсОшд & Пш_Інтенс & Пш_РсВдн \\
\hline Оплата праці & 19,08 & 22,85 & 28,06 & 26,70 \\
\hline Насіння & 179,28 & 79,68 & 203,60 & 179,21 \\
\hline Добрива & 371,25 & 271,64 & 463,76 & 556,63 \\
\hline Паливно-мастильні матеріали & 106,77 & 105,97 & 205,95 & 164,82 \\
\hline Засоби хімічного захисту & 144,88 & 434,62 & 95,01 & 126,71 \\
\hline Інше & 15,20 & 14,03 & 14,80 & 13,24 \\
\hline Разом & 836,46 & 928,80 & 1011,18 & 1067,31 \\
\hline на 1 га & 8,36 & 9,29 & 10,11 & 10,67 \\
\hline Оцінка впливу на стан ресурсного потенціалу & -2 & 0 & -1 & 1 \\
\hline
\end{tabular}

Джерело: розроблено авторами

Використання ресурсовиснажного режиму вирощування озимої пшениці (Пш_РcBcн) на площі 1 га вимагає витрачання набагато меншого обсягу

7 погіршення стану ресурсного потенціалу на 2 одиниці. Таким чином, технологію Пш РсВдн можна назвати інтенсивною, а технологію Пш_РcВсн екстенсивною. Аналогічним чином формуються таблиці за технологічними рішеннями інших культур сівозміни (табл. 3-5).

Таблиия 3

Основні параметри проєктних режимів ресурсокористування для вирощування кукурудзи на зерно (Кк) на 100 га посівної площі, тис. грн.

\begin{tabular}{|l|c|c|c|c|}
\hline \multicolumn{1}{|c|}{ Параметри } & Кк_РсОшд & Кк_РсВсн & Кк_Інтенс & Кк_РсВдн \\
\hline Оплата праці & 40,42 & 31,70 & 51,94 & 87,26 \\
\hline Насіння & 116,22 & 191,16 & 94,67 & 375,06 \\
\hline Добрива & 1014,49 & 0,00 & 91,48 & 688,62 \\
\hline Паливно-мастильні матеріали & 266,43 & 228,52 & 299,45 & 422,40 \\
\hline Засоби хімічного захисту & 0,00 & 32,28 & 12,00 & 30,01 \\
\hline Інше & 24,94 & 18,84 & 91,73 & 235,65 \\
\hline Разом & 1462,50 & 502,50 & 641,25 & 1839,00 \\
\hline на 1 га & 14,63 & 5,03 & 6,41 & 18,39 \\
\hline Оцінка впливу на стан ресурсного потенціалу & 0 & -2 & -1 & 1 \\
\hline
\end{tabular}

Джерело: розроблено авторами

Наступний етап полягає у визначенні техніко-економічної оцінки кожної альтернативи дії на заданих етапах при формуванні певного стану ресурсного потенціалу. Для організації зв'язку періодів приймаємо умову, при якій на кожному етапі відбувається отримання доходу від реалізації попередньої культури і здійснюються витрати на вирощування поточної культури.

Наприклад, на 2 етапі отримано дохід від реалізації зерна пшениці і далі вирощується кукурудза на зерно. Це відповідає реальності, коли сільськогосподарські виробники воліють реалізовувати урожай навесні при формуванні сприятливої кон'юнктури аграрного ринку. 
Так як сівозміна є циклічним механізмом, то на першому етапі вхідним потоком є дохід від реалізації насіння соняшнику при заданому рівні стану ресурсного потенціалу.

Таблиия 4

Основні параметри проектних режимів ресурсокористування для

вирощування ярого ячменю на 100 га посівної площі, тис. грн.

\begin{tabular}{|l|c|c|c|c|}
\hline \multicolumn{1}{|c|}{ Параметри } & Яч_РсОщд & Яч_РсВсн & Яч_Інтенс & Яч_РсВдн \\
\hline Оплата праці & 28,32 & 28,45 & 12,87 & 25,48 \\
\hline Насіння & 151,27 & 171,79 & 171,78 & 171,90 \\
\hline Добрива & 471,85 & 176,08 & 105,65 & 406,53 \\
\hline Паливно-мастильні матеріали & 174,21 & 119,06 & 76,37 & 160,34 \\
\hline Засоби хімічного захисту & 0,00 & 27,92 & 73,65 & 67,04 \\
\hline Інше & 15,59 & 16,33 & 15,96 & 15,97 \\
\hline Разом & 841,23 & 539,63 & 456,28 & 847,25 \\
\hline на 1 га & 8,41 & 5,40 & 4,56 & 8,47 \\
\hline Оцінка впливу на стан ресурсного потенціалу & 0 & -2 & -1 & 1 \\
\hline
\end{tabular}

Джерело: розроблено авторами

Наприклад, на 2 етапі отримано дохід від реалізації зерна пшениці і далі вирощується кукурудза на зерно. Це відповідає реальності, коли сільськогосподарські виробники воліють реалізовувати урожай навесні при формуванні сприятливої кон'юнктури аграрного ринку. Так як сівозміна $\epsilon$ циклічним механізмом, то на першому етапі вхідним потоком $є$ дохід від реалізації насіння соняшнику при заданому рівні стану ресурсного потенціалу.

Таблиия 5

Основні параметри проектних режимів ресурсокористування для вирощування соняшнику на 100 га посівної площі, тис. грн.

\begin{tabular}{|l|c|c|c|c|}
\hline \multicolumn{1}{|c|}{ Параметри } & Сн_РсВдн & Сн_Інтенс & Сн_РcBсн & Сн_РсОщд \\
\hline Оплата праці & 35,90 & 35,92 & 42,99 & 39,15 \\
\hline Насіння & 54,59 & 38,21 & 63,66 & 145,48 \\
\hline Добрива & 195,60 & 32,75 & 72,75 & 316,88 \\
\hline Паливно-мастильні матеріали & 250,80 & 251,53 & 327,50 & 289,67 \\
\hline Засоби хімічного захисту & 454,88 & 18,19 & 36,38 & 63,65 \\
\hline Інше & 11,40 & 8,67 & 7,88 & 11,00 \\
\hline Разом & 1003,16 & 383,80 & 551,15 & 865,83 \\
\hline на 1 га & 10,03 & 3,84 & 5,51 & 8,66 \\
\hline Оцінка впливу на стан ресурсного потенціалу & 1 & -1 & -1 & 1 \\
\hline
\end{tabular}

Джерело: розроблено авторами

Розрахункові таблиці визначення оптимального плану, що забезпечує оптимальний баланс ресурсокористування і ресурсозбереження, для кожного етапу i стану ресурсного потенціалу. Визначення плану здійснюється виявленням максимального значення прибутку при поточному стані ресурсного потенціалу, динаміка якого визначається впливом технологій обробітку на поточний стан.

Отже, за результатами експериментальної апробації пропонованих рішень на базі моделювання типових моделей технологічних прийомів сільськогосподарських підприємств відносно реалізації ресурсного потенціалу для реалізації головної мети господарської діяльності - максимізації 
прибутковості, - отримано наступний оптимальний план, який відображено на рис. 1.

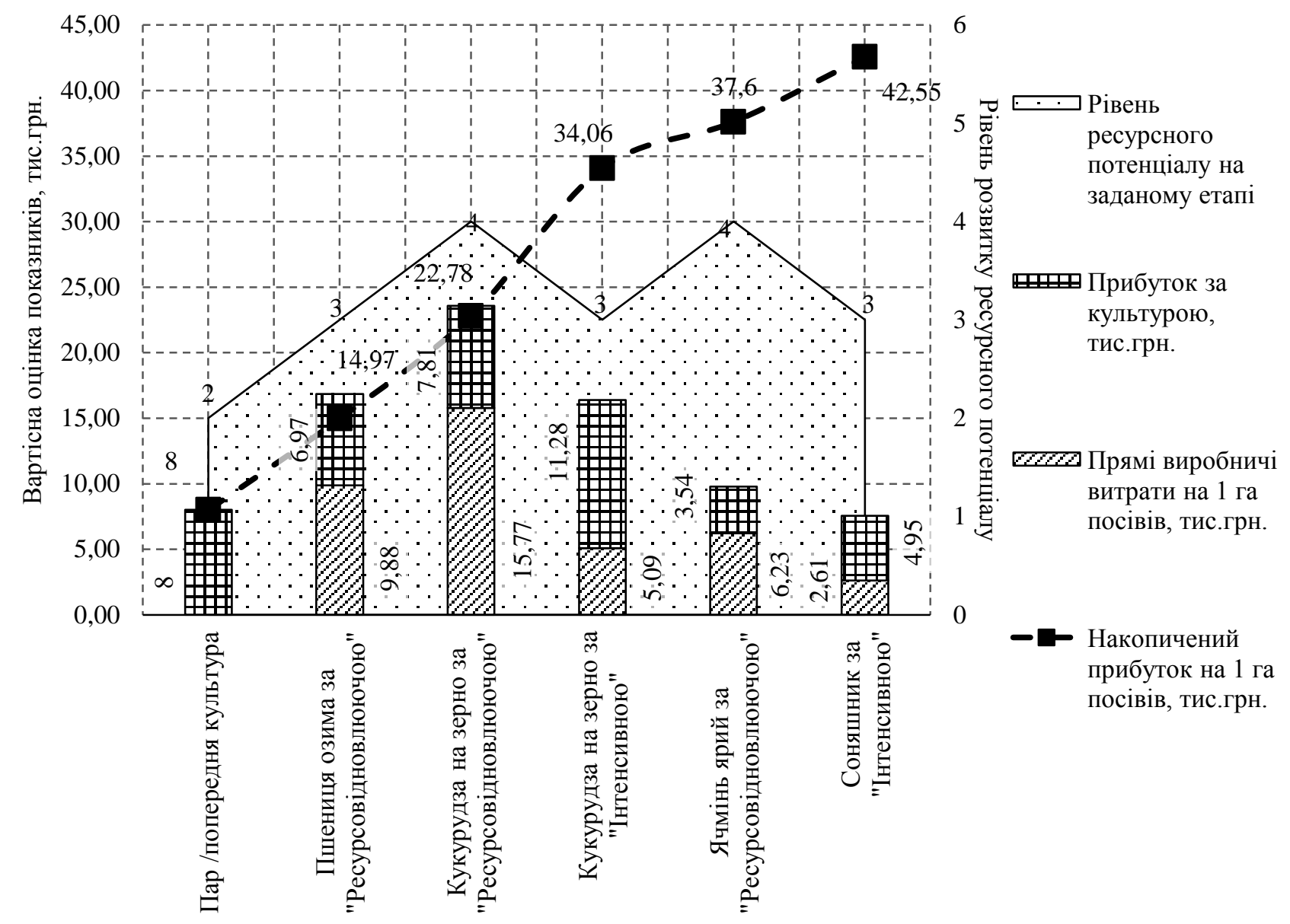

Рис. 1. Діаграма оптимального плану управління ресурсним потенціалом аграрного підприсмства в забезпеченні прибутковості рослинництва

Джерело: розроблено авторами

Зазначений план представляє собою рекомендований вибір технологічних прийомів обробітку культур для максимізації ефективності використання ресурсного потенціалу 3 метою збільшення прибутковості рослинництва. Вихідною умовою розробки плану реалізації ресурсного потенціалу $\epsilon$ забезпечення ресурсною основою сільськогосподарського виробництва на задовільному рівні. Цей показник $є$ узагальненим від оцінки сукупності ресурсів, необхідних для сільськогосподарського виробництва: земельних, агрокліматичних, трудових ресурсів, технічного забезпечення та інше. В самому простому розумінні, задовільний рівень ресурсного забезпечення можна оцінити продуктивністю основного ресурсу - посередньою родючістю сільськогосподарських угідь.

Головна ціль діяльності сільськогосподарських підприємств відображена на діаграмі у вигляді накопиченого прибутку на 1 га посівів в заданій системі типової сівозміни в умовах Луганської області. Зміна кута нахилу при переході від однієї культури до іншої свідчить про зміну маржинальної прибутковості 
економічної моделі вирощування культур. Чим більший кут нахилу, тим більшу прибутковість має наступна культура відносно попередньої. Можна зазначити, що різна результативність $\epsilon$ наслідком, як зміни обсягу витрат на обробіток культур, так і рівня дохідності за рахунок іншої ціни на продукцію i ефективності реалізації ресурсного потенціалу. Ступінь реалізації ресурсного потенціалу сільськогосподарського підприємства визначається здатністю отримувати прибуток при збереженні лімітованих ресурсів.

Отже, максимальний прибуток, який можливо отримати в заданих умовах 3 врахуванням зміни вартості грошей в часі складає 42,55 тис. грн. на 1 га площі сівозміни за 5-ти річний цикл типової сівозміни. Щодо зміни ресурсного потенціалу, то оптимальний план характеризується позитивною динамікою зі зміною якісного стану ресурсної основи від задовільного на початок проектованої сівозміни до доброго - на кінець періоду проекту. Цей результат зумовлений наступною послідовністю типових технологічних рішень сільськогосподарських підприємств на відповідному етапі дій:

Передпроектний етап (1 рік) - ідентифікація ресурсного потенціалу на початку нового (або чергового) виробничого циклу. 3 урахуванням умови відстроченої реалізації отриманої продукції від культивованих культур, отриманий дохід від реалізації $\epsilon$ умовно стартовим капіталом для покриття витрат на вирощування першої культури. Тому чистий пар у заданій системі має відповідний рівень забезпечення доходом, який дорівнює доходу останньої культури попереднього виробничого циклу.

1 етап (2 рік) - для отримання максимального прибутку в сівозміні при вирощуванні озимої пшениці використовується ресурсовідновлюючий тип технологій, який забезпечує прогрес ресурсного потенціалу до доброго рівня та забезпечує прибуток у 6,97 тис. грн. при 9,88 тис. грн. прямих виробничих витрат;

2 етап (3 рік) - 1 етап (2 рік) - отримані на попередньому етапі результати стають основою для підвищення ефективності реалізації ресурсного потенціалу на етапі першого обробітку кукурудзи на зерно у сівозміні, для якої оптимальним $\epsilon$ використання ресурсовідновлюючого типу технологій, що забезпечує прогрес ресурсного потенціалу до найкращого рівня та забезпечує прибуток у 7,81 тис. грн. при 15,77 тис. грн. прямих виробничих витрат;

3 етап (4 рік) - отримані на попередньому етапі результати для другої культивації кукурудзи на зерно створюють достатні умови використання інтенсивного типу технологій сільськогосподарських підприємств, що забезпечує більший приріст прибутку в 11,28 тис. грн. (що на 44,4\% менше від ресурсовідновлюючого типу) при 5,09 тис. грн. прямих виробничих витрат, але супроводжується негативною динамікою використання ресурсного потенціалу. Проте дане зниження відбувається в прийнятних межах;

4 етап (5 рік) - за оптимальним планом негативна динаміка ресурсного потенціалу 3 етапу компенсується за рахунок використання ресурсовідновлюючого типу технологій при культивації ярого ячменю. Цей вибір забезпечує підняття ресурсного потенціалу на найвищій рівень та 
отримання прибутку в 3,54 тис. грн. на 1 га площі сівозміни при 6,23 тис. грн. прямих виробничих витрат;

5 етап (6 рік) - останній етап циклу сівозміни характеризується використанням інтенсивного типу технологій вирощування соняшнику з метою максимізації прибутковості від найкращих цінових пропозицій на ринку сільськогосподарської продукції. Сформований найкращий стан ресурсного потенціалу стає ефективною основою забезпечення прибутковості соняшнику в 4,95 тис. грн. на 1 га посівів при 2,61 тис. грн. прямих виробничих витрат та збереженні прийнятного рівня ресурсного потенціалу (на рівні доброго стану).

Таким чином, загальний прибуток складає 42,55 тис. грн. на 1 га площі сівозміни при доброму остаточному стані ресурсного потенціалу. Наступний виробничий цикл планується аналогічно, але вже 3 добрим початковим станом ресурсного потенціалу.

Очевидно, що оптимальність пропонованого плану за пропонованою методикою із урахуванням фактору часу має на увазі безальтернативне домінування в показниках прибутковості, як індикатору ефективної реалізації ресурсного потенціалу. Тому наступним етапом $\epsilon$ порівняльний аналіз основних підходів до забезпечення прибутковості з оптимальним планом для перевірки плану на оптимальність.

Однією із найбільш поширених практик управління з метою забезпечення максимізації прибутку можна назвати економію на фінансових та виробничих pecypcax сільськогосподарського підприємства. Джерелом додаткового прибутку в даному випадку виступають кошти, що не були витрачені на додаткові виробничі операції.

Очевидно, що даний підхід не є безмежним, оскільки є базовий набір критичних технологічних завдань, наприклад, посів, збирання врожаю. Отже, додержання економічного плану використання ресурсного потенціалу в системі сівозміни означає вибір найдешевших варіантів технологічних прийомів вирощування сільськогосподарських культур.

На рис. 2 представлено план технологічних дій щодо реалізації ресурсного потенціалу, виходячи 3 пріоритетності економії фінансових ресурсів.

Отже, дані діаграми економічного плану свідчать про те, що додержання цього плану передбачає використання природних резервів ресурсного потенціалу для забезпечення результативності, що відображається критичним рівнем ресурсного потенціалу впродовж всього періоду часу. За озимою пшеницею та кукурудзою на зерно на обох етапах для забезпечення максимальної прибутковості необхідно використовувати ресурсовиснажальні типи технології. Для ярого ячменя та соняшника такими типами технології $\epsilon$ інтенсивні. Проте, за озимою пшеницею, ярим ячменем та соняшником ці критичні для ресурсного потенціалу технології не створюють прибуток, а тільки мінімізують вірогідний збиток. Як результат, ресурсовиснажуваний тип господарювання призводить до неможливості отримувати фінансовоекономічний результат: максимальний прибуток, на який можна розраховувати складає 7,93 тис. грн. на 1 га площі сівозміни за 5-ти річний цикл типової 
сівозміни Луганської області. Цей результат складає лише $18,64 \%$ від результату оптимального плану, що доводить ефективність оптимального плану відносно економічного плану.

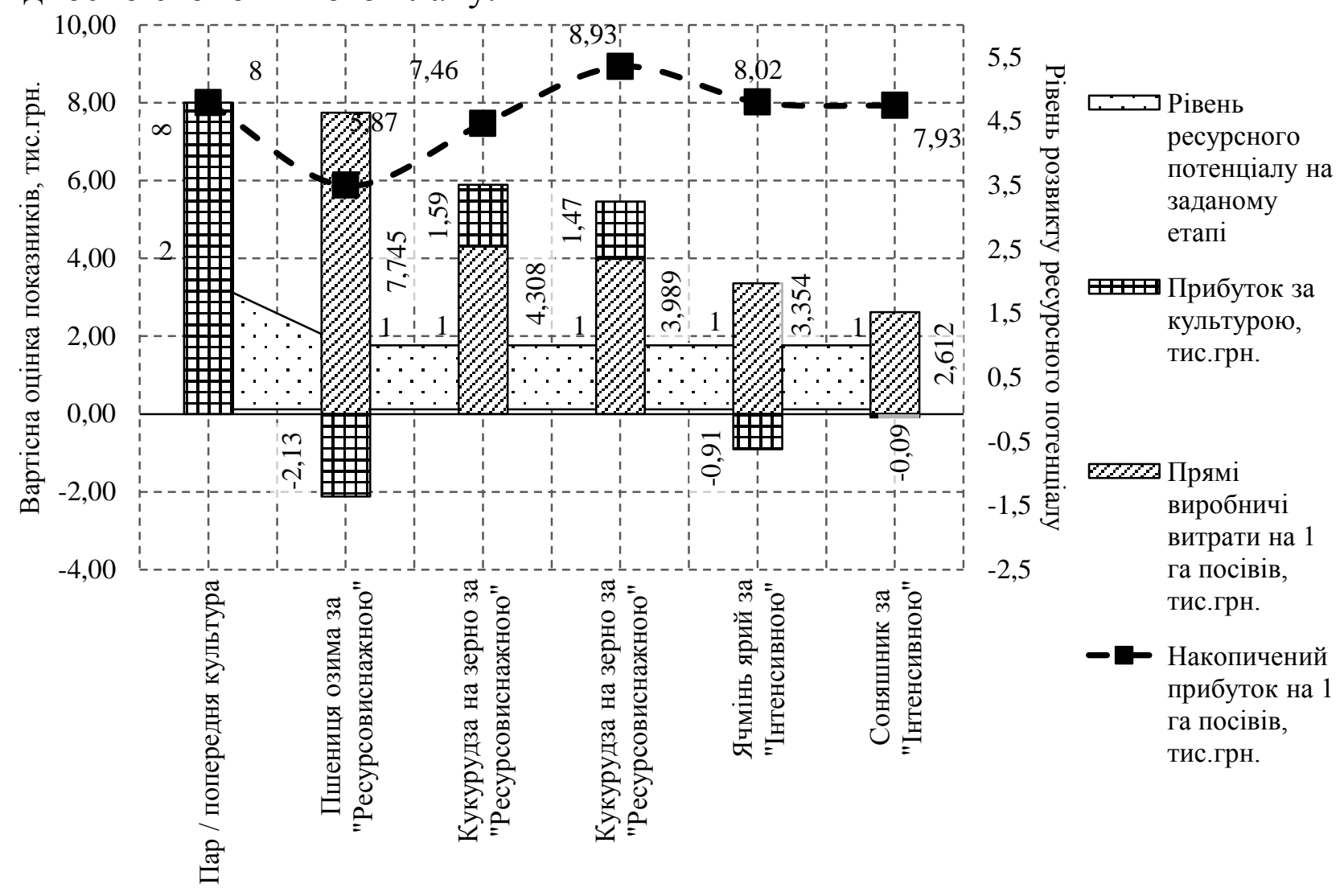

Рис. 2. Діаграма економічного плану управління ресурсним потенціалом аграрного підприємства в забезпеченні прибутковості рослинництва

Джерело: розроблено авторами

Не менш дієвою практикою антикризового управління для забезпечення сталого рівня прибутковості в умовах діяльності із залученням природних ресурсів вважається стратегія екологічної і соціальної спрямованості та зниження економічного навантаження на виробничі системи. Отже, іншою альтернативою, яка може конкурувати 3 оптимальним планом $\epsilon$ ресурсоощадний план, тобто вищий пріоритет при плануванні надається збереженню поточного стану, мінімальні зрушення у сторону покращення та недопущення зниження ресурсного потенціалу.

На рис. 3 представлено план технологічних дій щодо реалізації ресурсного потенціалу, виходячи 3 пріоритетності ощадного використання ресурсів у господарській практиці.

Таким чином, дотримання пріоритету ощадного відношення до ресурсного потенціалу в процесі господарської діяльності формує умови сталого ресурсокористування. За даними діаграми стан ресурсного потенціалу зберігається на рівні базового (задовільного) впродовж всього періоду, підвищуючись на останньому етапі до доброго. Але ця практика є сумнівною у 
плані забезпечення фінансово-економічного результату. Прибутковими в рамках ресурсоощадної діяльності за планом виявилися лише озима пшениця 3 прибутком в 2,64 тис. грн. при 8,60 тис. грн. прямих виробничих витрат; та соняшник з прибутком в 1,67 тис. грн. при 5,89 тис. грн. прямих виробничих витрат.

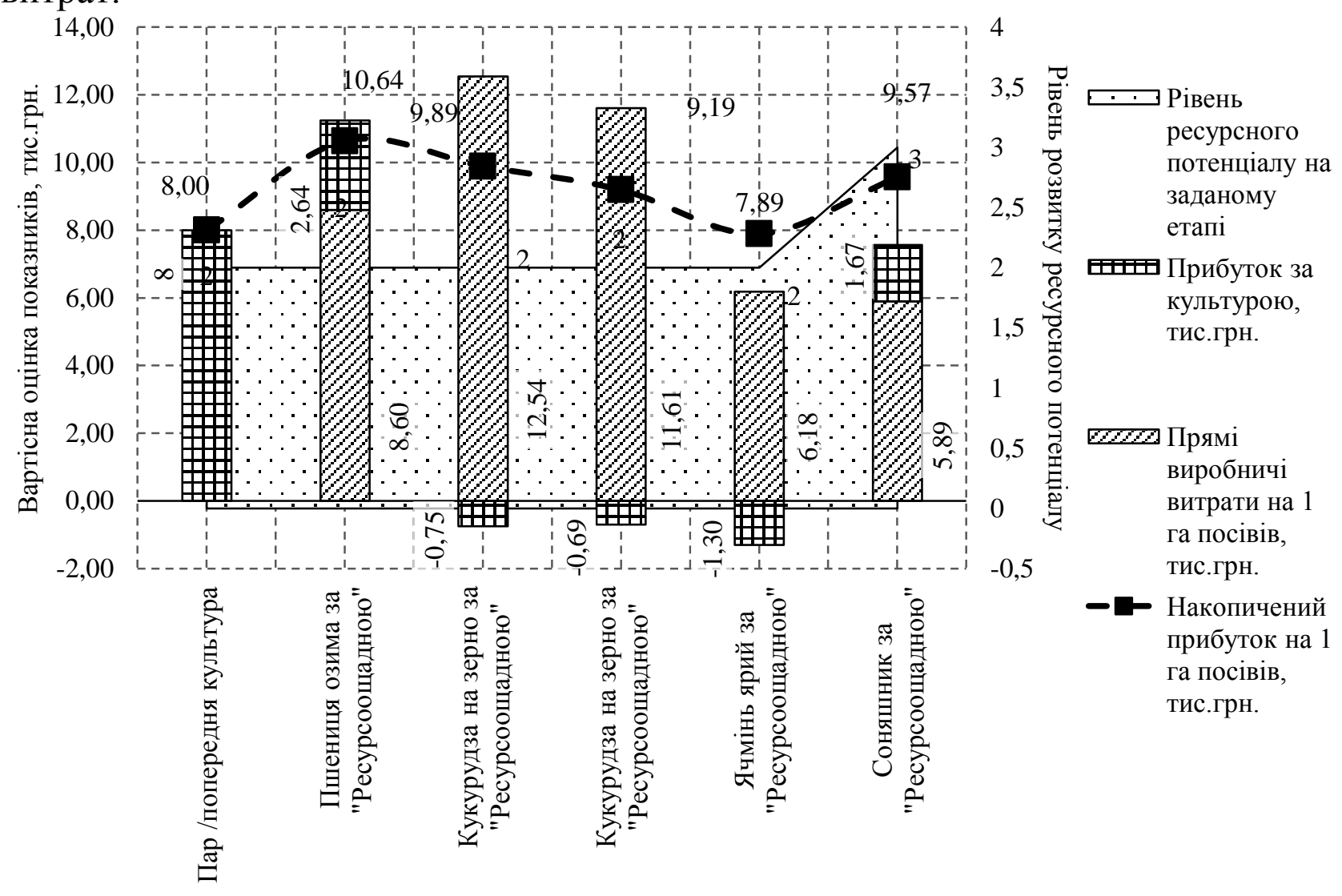

Рис. 3. Діаграма ресурсощадного плану управління ресурсним потенціалом аграрного підприсмства в забезпеченні прибутковості рослинництва

Джерело: розроблено авторами

Культивація кукурудзи на зерно та ярого ячменю у поточних умовах потребує додаткових інвестиційних витрат для забезпечення прибутковості.

Як результат, ресурсоощадний тип господарювання призводить до наступного фінансово-економічного результату: максимальний прибуток, на який можна розраховувати складає 9,57 тис. грн. на 1 га площі сівозміни за 5-ти річний цикл типової сівозміни Луганської області. Цей результат складає лише $22,50 \%$ від результату оптимального плану, що доводить ефективність оптимального плану відносно ресурсощадного.

На значний додатковий прибуток розраховують також підприємства, які, маючи достатні резерви фінансових та інвестиційних ресурсів, керуються технологічними рішеннями з пріоритетним завданням збільшення ресурсного потенціалу, тобто забезпечення умов зростання родючості грунтів, підвищення кваліфікації трудових ресурсів і тому подібне. Розглянемо 
ресурсовідновлюючий план, де вищий пріоритет при плануванні надається підвищенню поточного стану та недопущення його зниження.

На рис. 4 представлено план технологічних дій щодо реалізації ресурсного потенціалу, виходячи 3 пріоритетності ресурсовідновлення в господарській практиці.

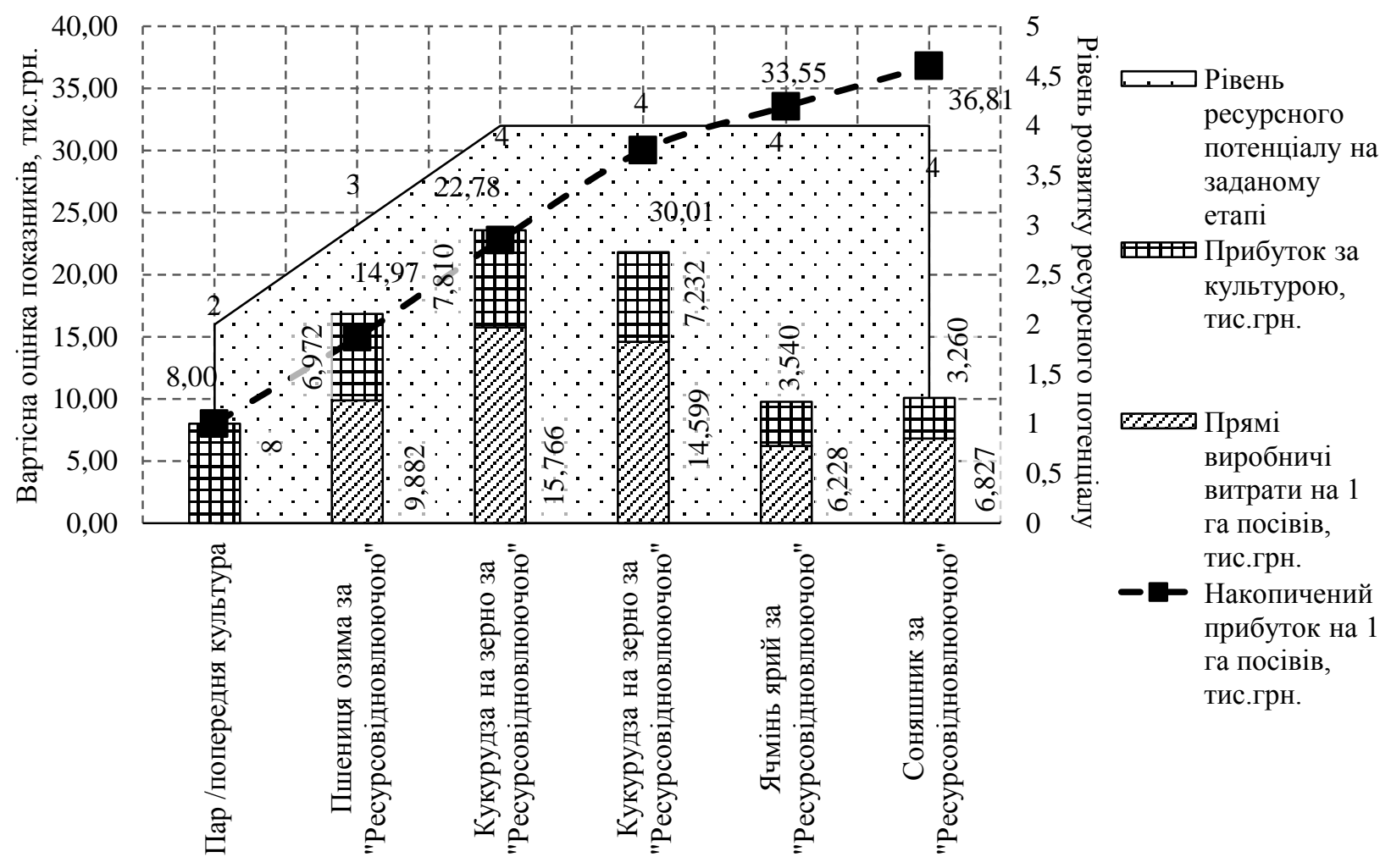

\section{Рис. 4. Діаграма інтенсивного плану управління ресурсним потенціалом аграрного підприємства в забезпеченні прибутковості рослинництва}

Джерело: розроблено авторами

Виходячи $з$ даних діаграми ресурсовідновлюючого плану (рис. 4) робимо висновки, що така стратегія забезпечує максимально наближену до оптимального плану програму поводження з ресурсним потенціалом.

Ресурсовідновлюючий план забезпечує поступове підняття ресурсного потенціалу до найкращого рівня та підтримку цього стану впродовж всього періоду. Це задовольняє умови розвитку сталого рослинництва, проте дещо обмежує підприємницькі інтереси сільськогосподарських підприємств. В даному плані за всіма культурами спостерігається отримання прибутку, але ресурсні інтереси обмежують його рівень. Така ситуація спостерігається на етапі другої культивації кукурудзи на зерно, коли отримано прибуток в 7,23 тис. грн. на 1 га посівів при 14,60 тис. грн. прямих виробничих витрат, що у порівнянні 3 показниками оптимального плану на $35,9 \%$ менше у прибутковості та втричі більше за прямими виробничими витратами; та на останньому етапі вирощування соняшнику, коли отримано прибуток в 3,26 тис. грн. на 1 га посівів при 6,827 тис. грн. прямих виробничих витрат, що 
у порівнянні 3 показниками оптимального плану на $34,14 \%$ менше у прибутковості та в 2,6 більше за прямими виробничим витратами. Як результат, ресурсовідновлюючий тип господарювання призводить до наступного фінансово-економічного результату: максимальний прибуток, на який можна розраховувати складає 38,61 тис. грн. на 1 га площі сівозміни за 5-ти річний цикл типової сівозміни Луганської області. Цей результат складає на 13,5\% менше від результату оптимального плану, що доводить ефективність оптимального плану відносно ресурсовідновлюючого плану.

Таким чином, за результатами порівняльного аналізу з альтернативними сценаріями розвитку практики управління ресурсним потенціалом доведено ефективність оптимального плану.

Висновки. Проаналізовано передумови формування оптимального плану управління ресурсним потенціалу сільськогосподарського підприємства, що дозволяє отримати максимальний прибуток із забезпеченням прийнятної динаміки змін ресурсного потенціалу.

Встановлено, що максимальний рівень економічної віддачі можливий за умови відповідного чергування ресурсовідновлюючого та інтенсивного режиму ресурсокористування. Причому, використання ресурсовиснажливого режиму $є$ неефективним навіть в особливих економічних умовах через те, що післядія виснажливого господарювання критично знижує ресурсний потенціал аграрного підприємства.

Обгрунтовано, що оптимальний план за пропонованим механізмом управління ресурсним потенціалом має спільні риси з інтенсивним режимом ніж 3 ресурсовідновлюючим, що свідчить про пріоритетну господарську спрямованість оптимального управління виробничими ресурсами, а ресурсовідновлювальна практика $\epsilon$ необхідним інструментом забезпечення сталого рівня ресурсного потенціалу.

За результатами порівняльного аналізу з альтернативними сценаріями розвитку практики управління ресурсним потенціалом доведено ефективність оптимального плану.

Перспективи подальших досліджень пов'язані з вивченням питань щодо використання принципів динамічного програмування в системі управління ресурсним потенціалом аграрних підприємств із метою покращення використання ресурсів, підвищення рівня рентабельності та рівня конкурентоспроможності аграрних підприємств на ринку рослинницької продукції.

\section{Список використаних джерел}

1. Белоусенко М.В. Экономическая организация: ресурсноориентированный подход. Научные труды ДонНТУ. Серия: экономическая. 2008. Вып. 34-1. С. 190-197.

2. Вініченко І.І., Сорока Ю.О. Ефективність використання ресурсного потенціалу сільськогосподарських підприємств. Інвестииї: практика та досвід. 2015. № 22. С. 34-37. 
3. Сидорук Б., Ящук Т., Сидорук Г. Оцінка впливу структури посівних площ сільськогосподарських культур на якісний стан земельних угідь. Економічний дискурс. Міжнародний науковий журнал. 2020. Вип. 2. С. 37-45.

4. Міценко Н.Г., Кумечко О.I. Ресурсний потенціал підприємства: сутність, структура, стратегія використання. Науковий вісник національного лісотехнічного університету Украӥни : збірник науково-технічних пращь. 2010. Т. 20. № 9. С. 193-198.

5. Піняга Н.О. Вивчення потреби ресурсного потенціалу сільськогосподарських підприємств системним підходом. Агросвіт. 2013. № 9. C. 62-64.

6. Россоха В.В. Теоретико методичні засади формування, розвитку та оцінювання виробничого потенціалу сільськогосподарського підприємства. К.: ННЦ IAЕ, 2013. 94 c.

7. Сердак С.Е. Принципи ефективного управління ресурсами суб'єктів господарювання. Академічний огляд. 2008. № 2. С. 83-88.

8. Трегобчук В.М. Відтворення та ефективність використання ресурсного потенціалу АПК (теоретичні та практичні аспекти) / Відп. редактор акад. УААН B.М. Трегобчук. К.: ННЦ IAE, 2003. 259 с.

9. Туровець О. Формування системи пріоритетів в управлінні потенціалом розвитку підприємства. Економіка Украйни. 2005. № 10. С. 24-28.

10. Федонін О.С., Рєпіна I.М., Олексюк О.I. Потенціал підприємства: формування та оцінка: монографія. Київ, 2004. 316 с.

\section{References}

1. Belousenko, M.V. (2008). Jekonomicheskaja organizacija: resursnoorientirovannyj podhod [Economic organization: resource-oriented approach]. Nauchnye trudy DonNTU. Serija: jekonomicheskaja - Scientific works of DonNTU. Series: economic, 34-1, 190-197 [in Russian].

2. Vinichenko, I.I. (2015). Efektyvnist vykorystannia resursnoho potentsialu silskohospodarskykh pidpryiemstv [Efficiency of using the resource potential of agricultural enterprises]. Investytsii: praktyka ta dosvid - Investments: practice and experience, 22, 34-37 [in Ukrainian].

3. Sidoruk, B., Yashchuk, T., \& Sidoruk, G. (2020). Estimation of the influence of the structure of sown areas of agricultural crops on the quality of land. Economic discourse. International scientific journal, 2, 37-45. [in Ukrainian].

4. Mitsenko, N.H., \& Kumechko, O.I. (2010). Resursnyi potentsial pidpryiemstva: sutnist, struktura, stratehiia vykorystannia [Resource potential of the enterprise: essence, structure, strategy of use]. Vestnyk NLU - Bulletin NFEU, 20, 9, 344-352 [in Ukrainian].

5. Piniaha, N.O. (2013). Vyvchennia potreby resursnoho potentsialu silskohospodarskykh pidpryiemstv systemnym pidkhodom [The study of the resource potential needs of agricultural enterprises with a systematic approach]. Ahrosvit Agroworld, 20 (9), 62-64 [in Ukrainian].

6. Rossokha, V.V. (2013). Teoretyko metodychni zasady formuvannia, rozvytku ta otsiniuvannia vyrobnychoho potentsialu silskohospodarskoho pidpryiemstva 
[Theoretical and methodological foundations of formation, development and evaluation of the production potential of agricultural enterprises]. Kyiv: NNTs «IAE» [in Ukrainian].

7. Serdak, S.E. (2008). Pryntsypy efektyvnoho upravlinnia resursamy subiektiv hospodariuvannia [The principles of effective management of resources of economic entities]. Akademichnyi ohliad-Academic review, 2, 83-88 [in Ukrainian].

8. Trehobchuk, V.M. (2003). Vidtvorennia ta efektyvne vykorystannia resursnoho potentsialu APK (teoretychni i praktychni aspekty) [Reproduction and effective use of the resource potential of the agro-industrial complex (theoretical and practical aspects)]. Kyiv: NNTs «IAE» [in Ukrainian].

9. Turovets, O. (2005). Formuvannia systemy priorytetiv $\mathrm{v}$ upravlinni potentsialom rozvytku pidpryiemstva [Formation of a system of priorities in managing the potential of enterprise development]. Ekonomika Ukrainy - Economy of Ukraine, 10, 24-28 [in Ukrainian].

10. Fedonin, O.S. Potentsial pidpryiemstva: formuvannia ta otsinka [Potential of the enterprise: formation and evaluation]. Kyiv: KNEU [in Ukrainian].

\section{Відомості про авторів}

КОЧЕТКОВ Олексій Васильович - кандидат економічних наук, професор, завідувач кафедри менеджменту, права, статистики та економічного аналізу Луганського національного аграрного університету (62341, Харківська область, Дергачівський район, с. Мала Данилівка, вул. Академічна, 5, кв. 57, e-mail: avkochetkov@ukr.net).

АФАНАСОВА Юлія Олександрівна - аспірантка четвертого року навчання кафедри менеджменту, права, статистики та економічного аналізу Луганського національного аграрного університету (92003, Луганська область, м. Старобільськ, вул. Слобожанська, 68, e-mail: yafannasova@gmail.com).

KOCHETKOV Oleksii - PhD in Economics, Head of the Department of Management, Law, Statistics and Economic Analysis, Lugansk Nationa Agrarian University (62341, Kharkiv region, Derhachiv district, village Mala Danylivka, 557 Akademichna str., e-mail: avkochetkov@ukr.net).

AFANASOVA Julia - graduate student of the fourth year of study Department of Management, Law, Statistics and Economic Analysis, Lugansk National Agrarian University (92003, Luhansk region, Starobilsk, 68 Slobozhanska str., e-mail: yafannasova@gmail.com).

КОЧЕТКОВ Алексей Васильевич - кандидат экономических наук, профессор, заведующий кафедрой менеджмента, права, статистики и экономического анализа Луганского национального аграрного университета (62341, Харьковская область, Дергачевский район, пос. Малая Даниловка, ул. Академическая, 5, кв. 57, e-mail: avkochetkov@ukr.net).

АФАНАСОВА Юлия Александровна - аспирантка четвертого года обучения кафедры менеджмента, права, статистики и экономического анализа Луганского национального аграрного университета (92003, Луганська область, г. Старобельск, ул. Слобожанская, 68, e-mail: yafannasova@gmail.com). 